\title{
Epidemiological Pilot Study of the Sensitization to Caterpillars of the Genus Thaumetopoea in Forestry Workers in Bulgaria
}

\author{
YI Kandova, GS Nikolov*, BN Petrunov
}

National Center of Infectious and Parasitic Diseases, 1504 Sofia, Bulgaria

\section{Abstract}

Insect bites and Lepidopterism are a major sensitization hazard for forestry workers. In recent years, different species of the genus Thaumetopoea are expanding their habitat in Bulgaria and represent a serious health threat for people working in the forests. The present epidemiological pilot study aims to investigate the specific sensitization of the forestry workers to the caterpillars of the most spread Thaumetopoea species in Bulgaria, as well as to evaluate their hypersensitivity to a range of inhalant, insect and food allergens.Thirty four forestry workers (28 men and 6 women) were surveyed. The sensitization to pine processionary (Thaumetopoea pityocampa); oak processionary (Thaumetopoea processionea) and Thaumetopoea solitaria was assessed by skin prick tests. Blood samples were taken for determination of total and allergen-specific lgE against a range of inhalant, insect and food allergens. Fourteen (41\%) of the forestry workers reported skin rash, itching, runny nose and sneezing during their daily professional activities in the forest. Sixteen (47\%) were sensitized to one or more representatives of the Thaumetopoeidae family. The most common is poly-sensitization to all three Thaumetopoea species - in 6 (38\%), as well as mono-sensitization to pine processionary - in other 5 (31\%). In 13 (39\%) increased levels of total IgE, were found. A prevalence of insect allergy was also found. In conclusion, this pilot study provided important information on the impact of the different Thaumetopoea species on the health of the forestry workers. It also outlined the key role of different environmental allergens for the development of symptoms of lgE-mediated allergy and the need for more detailed epidemiologic and allergologic study on the medico-social importance of the sensitization to Thaumetopoea species.

Key words: epidemiological study, sensitization in forestry workers; allergy to Thaumetopoea pityocampa, allergy to Thaumetopoea processionea, insect allergy

No conflict of interest to declare.

For citation: Kandova YI, Nikolov GS, Petrunov BN. Epidemiological Pilot Study of the Sensitization to Caterpillars of the Genus Thaumetopoea in Forestry Workers in Bulgaria. Epidemiology and Vaccinal Prevention. 2020; 19 (1): 71-76 (In Russ.). https://doi: 10.31631/2073-3046-2020-19-1-71-76.

Эпидемиологическое пилотное изучение сенсибилизирующего действия к гусениц рода Thaumetopoea на организм работников лесного хозяйства Болгарии

Я. И. Кандова, Г. С. Николов**, Б. Н. Петрунов

Национальный центр инфекционных и паразитарных болезней, 1504 София, Болгария

\section{Резюме}

Актуальность: Укусы насекомых и гусениц являются основной опасностью сенсибилизации организма работников лесной промышленности. В течение последних лет различные виды рода Thaumetopoea расширяют своё местообитание в Болгарии и представляют серьёзную угрозу здоровью людей, работающих в лесу. Цель: исследовать специфическую сенсибилизацию к гусеницам наиболее распространённых видов Thaumetopoеa в Болгарии. Материалы и методы: В пилотном исследовании использовались эпидемиологические методы изучения (описательно-оценочные приемы). Обследованы 34 человека, работающих в лесной промышленности (28 мужчин и 6 женщин). Определение сенсибилизирующего действия южного походного шелкопряда (Thaumetopoea pityocampa), дубового походного шелкопряда (Thaumetopoea processionea) и Thaumetopoea solitaria проводили посредством кожных тестов. Взяты пробы крови для определения общего IgE и специфического IgE по отношению к ряду ингаляторных, инсектных и пищевых аллергенов. Результаты: Четырнадцать обследованных (42\%) отмечали аллергические реакции организма в течение ежедневной профессиональной деятельности в лесу. Шестнадцать обследованных (47\%) имели аллергию к одному или более представителям семейства Thaumetopoeidae. Чаще всего наблюдается множественная аллергия - к трём видам Thaumetopoea y 6 (38\%) человек. К южному походному шелкопряду была аллергия у 5 человек (31\%). У 13 человек (39\%) выявлен повышенный уровень общего IgE. Определение специфической сенсибилизации показывает распро-

\footnotetext{
${ }^{*}$ For correspondence: Georgi S. Nikolov, Dr. Sci. (Med.), Department «Immunology and Allergology», NCIPD, labalerg@ncipd.org.

** Николов Георгий Сергеевич, д. м. н., кафедра Иммунологии и аллергологии Национальногой центра инфекционных и паразитарных болезней, 1504 София, Болгария. labalerg@ncipd.org.
} 
странение аллергии к инсектам. Выводы: Исследование предоставило важную информацию о воздействии различных видов Thaumetopoea на здоровье работников лесной промышленности. Оно выявило ключевую роль различных аллергенов в окружающей среде для развития симптомов IgE-медиированной аллергии и необходимость более подробного эпидемиологического и аллергологического изучения медико-социальной значимости сенсибилизации к гусеницам наиболее распространённых видов Thaumetopoea в Болгарии.

Ключевые слова: эпидемиологическое исследование, сенсибилизация работников лесной промышленности, аллергия к Thaumetopoea pityocampa, аллергия к Thaumetopoea processionea; аллергия к инсектам Конфликт интересов не заявлен.

Для цитирования: Кандова Ю. И., Николов Г. С., Петрунов Б. Н.Эпидемиологическое пилотное изучение сенсибилизирующего действия к гусениц рода Thaumetopoea на организм работников лесного хозяйства Болгарии. Эпидемиология и Вакцинопрофилактика. 2020; 19 (1): 71-76. https://doi: 10.31631/2073-3046-2020-19-1-71-76.

\section{Introduction}

During most of their professional activities, forestry workers are in contact with various occupational pathogens from their environment. The usual routes of exposure include: inhalation, and skin penetration in the event of injury [1].

Insect bites are a major sensitization hazard for forestry workers. Bites and stings from wasps, bees, hornets, mosquitoes, ants and many other insects are common and usually occur with a local reaction that manifests with a rash and itching at the site of the bite. In sensitized individuals, acute, generalized, sometimes life-threatening allergic reactions may occur.

Sensitization to insects from the order Hymenoptera is common among forest workers from $4.5 \%$ to $26 \%$ [2]. In Italy, $78.0 \%$ of 100 forestry department agents reported accidental Hymenoptera stings. Five percent of them had experienced systemic reactions [3].

Another major cause of specific sensitization among forestry workers is so-called Lepidopterism pathological response of the organism after contact with insects of the order Lepidoptera, which includes both moths and butterflies [4,5]. Of the more than 165,000 species in this order, 150 larvae forms may prove to be harmful to humans due to direct or aerial contact of the skin or mucous membranes with their poisonous hairs (setae), which serve as a defense mechanism against predators, birds and small rodents [5]. In Europe, this is most often the case after contact with caterpillars of Thaumetopoeidae family - Thaumetopoea pityocampa (pine processionary); Thaumetopoea processionea (oak processionary) and Thaumetopoea solitaria.

Apart from various types of irritant and toxic skin reactions - known as caterpillar dermatitis, Lepidopterism may occur also as conjunctivitis, pharyngitis, respiratory distress, or various combinations of these symptoms.

In addition to the toxo-irritant reactions after contact with different caterpillars, in recent years there are plenty clinical evidences proving the presence of IgE-mediated allergy that manifests as allergic rhinitis or asthmatic attacks and even anaphylactic shock [6]. Therefore, Thaumetopoea caterpillars should be considered not only as a source of occupational contact allergy, but also as a specific aeroallergen that causes skin, inhalative, and ocular allergic symptoms that can affect the health of a wide range of the forest visitors [7].

Due to the climate changes on the planet in recent years, different species of the genus Thaumetopoea are expanding their habitat in Bulgaria and represent a serious occupational health threat for people working in the forests [8].

In this regard, the present pilot study of a group of forestry workers aims to investigate their specific sensitization to the caterpillars of the most spread Thaumetopoea species in Bulgaria, as well as to evaluate their hypersensitivity to a range of inhalant, insect and food allergens.

\section{Materials and methods \\ Surveyed persons}

The pilot study of sensitization to Thaumetopoea species in Bulgaria was conducted with a group of individuals working daily in the forests and having frequent contact with different types of processionary caterpillars. A total of 34 subjects were surveyed 28 men and 6 women between the ages of 26 and 87 .

After obtaining informed consent, project participants complete a specially designed questionnaire. Each participant was then subjected to a detailed allergic examination to determine the presence of allergic complaints while working in the forest and blood samples were taken to determine total IgE and allergen-specific IgE for a range of inhalant, insect and food allergens.

\section{Determination of sensitization in vivo to the most spread Thaumetopoea species in Bulgaria}

The specific sensitization to caterpillars of three Thaumetopoea species: pine processionary (Thaumetopoea pityocampa); oak processionary (Thaumetopoea processionea) and Thaumetopoea solitaria was assessed by allergy skin prick tests (SPT).

For this purpose in the Laboratory for Allergenic preparations at Bul Bio NCIPD, Sofia, Bulgaria, were prepared special diagnostic allergens from the above mentioned Thaumetopoea species.

As a raw material for the production of allergenic extracts, caterpillars in L4/L5 stage were collected 
Figure 1. Distribution of study participants after the initial examination for allergy

Рисунок 1. Распределение участников исследования после первичного обследования на аллергию

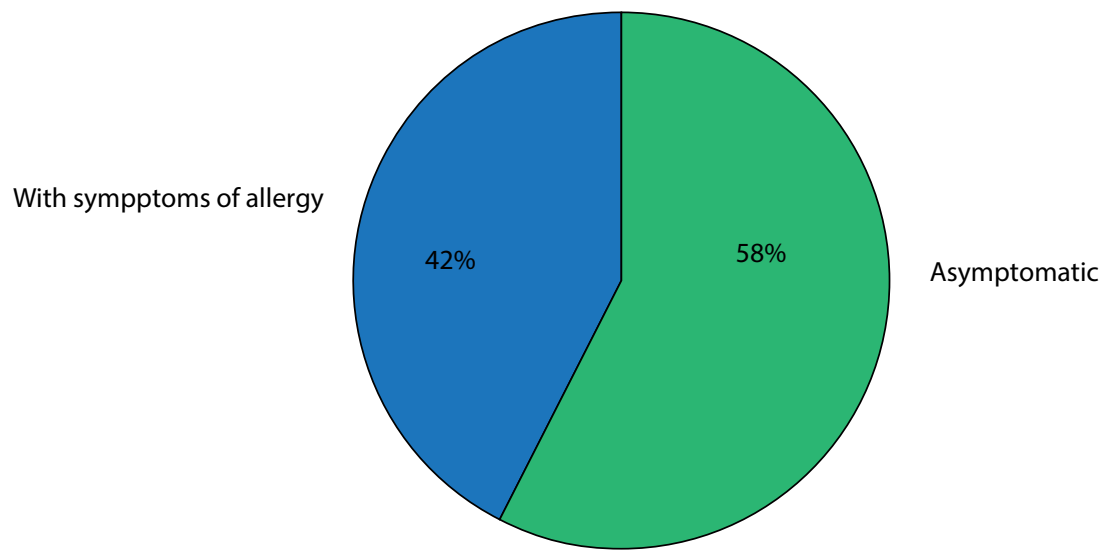

and provided by scientists from the Forest Research Institute at Bulgarian Academy of Sciences. Allergens were prepared by an original methodology consistent with the procedures for the production and standardization of allergens for allergy diagnosis by SPT in the conditions of Good Manufacturing Practice (GMP).

To prove the specificity of the allergens from studied Thaumetopoea species, 21 healthy, non-allergic and atopic volunteers, sensitized to grass pollen and/ or house dust mites, were tested with the above mentioned experimental extracts by Prick test and showed no positive skin reactions.

The diagnostic allergy skin tests were performed simultaneously with the allergens from the three Thaumetopoea caterpillars in a volume of $0.05 \mathrm{ml}$ on the volar side of the forearm of each participant. Negative (Coca I solution) and positive (histamine $1 \mathrm{mg} / \mathrm{ml}$ ) controls were applied in parallel. The reactions obtained were read at 20 minutes according to size of wheal and flare reaction. Size of wheal and flare with a mean diameter $>3 \mathrm{~mm}$ were considered positive.

\section{Determination of total IgE}

Quantification of total IgE was performed with an ELISA kit (EUROIMMUN) according to the manufacturer's instructions. Values above $100 \mathrm{IU} / \mathrm{ml}$ were considered elevated.

\section{Determination of allergen-specific IgE}

In 10 of the participants with total IgE levels above $100 \mathrm{IU} / \mathrm{ml}$, by determination of allergen-specific IgE, using a set of 34 inhalative, insect and food allergens (EUROLINE Atopy screen, EUROIMMUN), was examined the specific sensitization to any of the allergens included in the panel. The determination was made according to the manufacturer's instructions.
The calculation of the amount of allergen-specific IgE was made with software EUROLine Scan v. 3.4. by the intensity of the staining of the bands and was presented in EAST (Enzyme-Allergo-Sorbent Test) grade scale from 0 to 6 .

\section{Results}

At the initial examination for allergy, 14 (42\%) of the study participants reported allergic health problems during their daily professional activities in the forest (Figure 1).

The complaints were mainly from the skin (itching in 6 participants, rash in 7) and from upper respiratory tract (runny nose and sneezing - in 4 forestry workers). One reported eye irritation and 2 participants reported an allergic incident after insect sting.

Determination of total IgE found increased levels (above $100 \mathrm{IU} / \mathrm{ml}$ ) in 13 (39\%) of the studied subjects. Comparison of the total IgE levels with the history of allergic complaints showed the following: No elevated total IgE levels were found in 11 (34\%) of the asymptomatic individuals. In 5 (15\%) of the patients with complaints, an increased level of total IgE was observed. In the other 9 subjects who reported allergic symptoms, no increase in total lgE levels was found, and 8 in asymptomatic ones showed increased levels of the total IgE (Table 1).

Determination of the specific sensitization to different species of Thaumetopoea caterpillars was performed by skin-allergy tests using specially designed diagnostic allergens. The results from the skin tests showed that 16 (47\%) of the 34 study participants, mostly people with daily work in the forest, were sensitized to one or more representatives of the Thaumetopoeidae family. According to SPT data, the most common is poly-sensitization to all three Thaumetopoea allergens - in 6 (38\%) of the sensitized individuals, as well as mono-sensitization to the pine 


\section{Original Articles}

Table 1. Distribution of participants when comparing data on levels of total lgE with data from history of allergic complaints

Таблица 1. Распределение участников по уровню общего IgE и сведениями об аллергии в анамнезе

\begin{tabular}{|l|c|c|}
\hline \multicolumn{1}{|c|}{ Condition } & Number & $\%$ \\
\hline Symptoms - / tlgE - & 11 & 34 \\
\hline Symptoms + / tlgE+ & 5 & 15 \\
\hline Symptoms + / tlgE - & 9 & 27 \\
\hline Symptoms - / tlgE + & 8 & 24 \\
\hline
\end{tabular}

processionary (T. pityocampa) - in other 5 (31\%) participants. There were isolated cases of mono-sensitization to the oak processionary (Thaumetopoea processionea), and no such sensitization was observed to the Thaumetopoea solitaria (Figure 2).

Supplementation of the data for specific sensitization to different Thaumetopoea species to the results from the initial allergic examination and levels of total IgE demonstrate that of the 16 participants who showed hypersensitivity through positive skin tests, 7 (44\%) reported having allergic symptoms on contact with processionary caterpillars. It should be noted that only in three persons (19\%) the allergy complaints are accompanied by an increase in total IgE, i.e. this is the group where the IgE-mediated mechanism of symptoms is most probable. In the remaining 9 (56\%) participants, detected sensitization to caterpillar allergens is asymptomatic, but still in 5 of them sensitization is accompanied by increased levels of total lgE.

In 10 of the participants with a significant increase in total IgE, were determined allergen-specific lgE levels in a set of 34 inhalative, insect and food allergens. In all studied subjects were detected increased levels of specific IgE to one or more of the allergens used in a panel.

The results, presented in figure 3 , show that from 10 tested forestry workers 8 are sensitized to i3 (wasp allergen), and 5 to i1 (bee venom allergen). Allergy to grass pollens (g1, g3, g6 and g12) is also common. In 6 of the participants sensitized to one or more inhalative, insect or food allergens, was detected sensitization to Thaumetopoea caterpillars also.

\section{Discussion}

The results of our first pilot study of sensitization in forestry workers in Bulgaria demonstrate that the excessive contact with different Thaumetopoea species has a serious impact on their health. According to the data from the study, the representatives of the Thaumetopoea family cause a various allergic complaints in people who have daily contact with the caterpillars.

Skin reactions after contact with urticogenic hairs on their larvae are the most common clinical manifestations of exposure. The main symptoms observed in $42 \%$ of the participants in this study were severe itching, sometimes without visible skin lesions, in many cases there was rapid hives (contact urticaria) or late-onset papular itchy rash, which persists for several days. In most of our study participants, contact urticaria is IgE-mediated.

The pathogenic effects of the Thaumetopoea caterpillars are not limited to the skin. Upper respiratory tract involvement in the form of allergic runny nose, coughing, and difficulty

Figure 2. Distribution of the profile of sensitization to the different species of Thaumetopoea caterpillars, in study participants with positive allergy skin pricks tests

Рисунок 2. Распределение профиля сенсибилизации к различным видам гусениц Тhачтеtороеа у участников исследования с положительными аллергическими кожными пробами

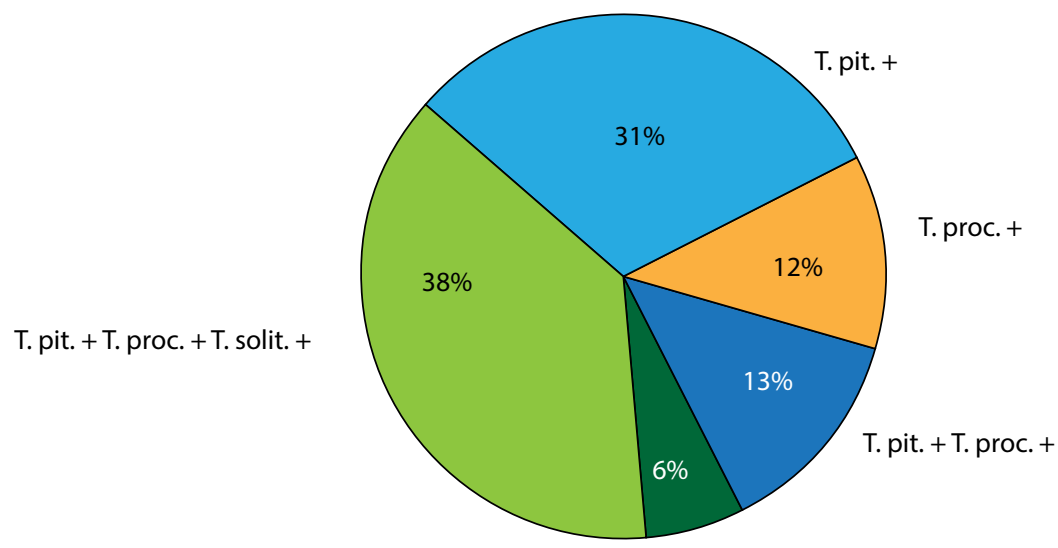

T. proc. + T. solit. + 
Figure 3. Sensitization in forest workers with increased total IgE to 34 inhalative, insect and food allergens

Рисунок 3. Аллергические реакции у работающих в лесу с повышенным общим IgE на 34 различных аллергена (ингаляционных, насекомых и пищевых)

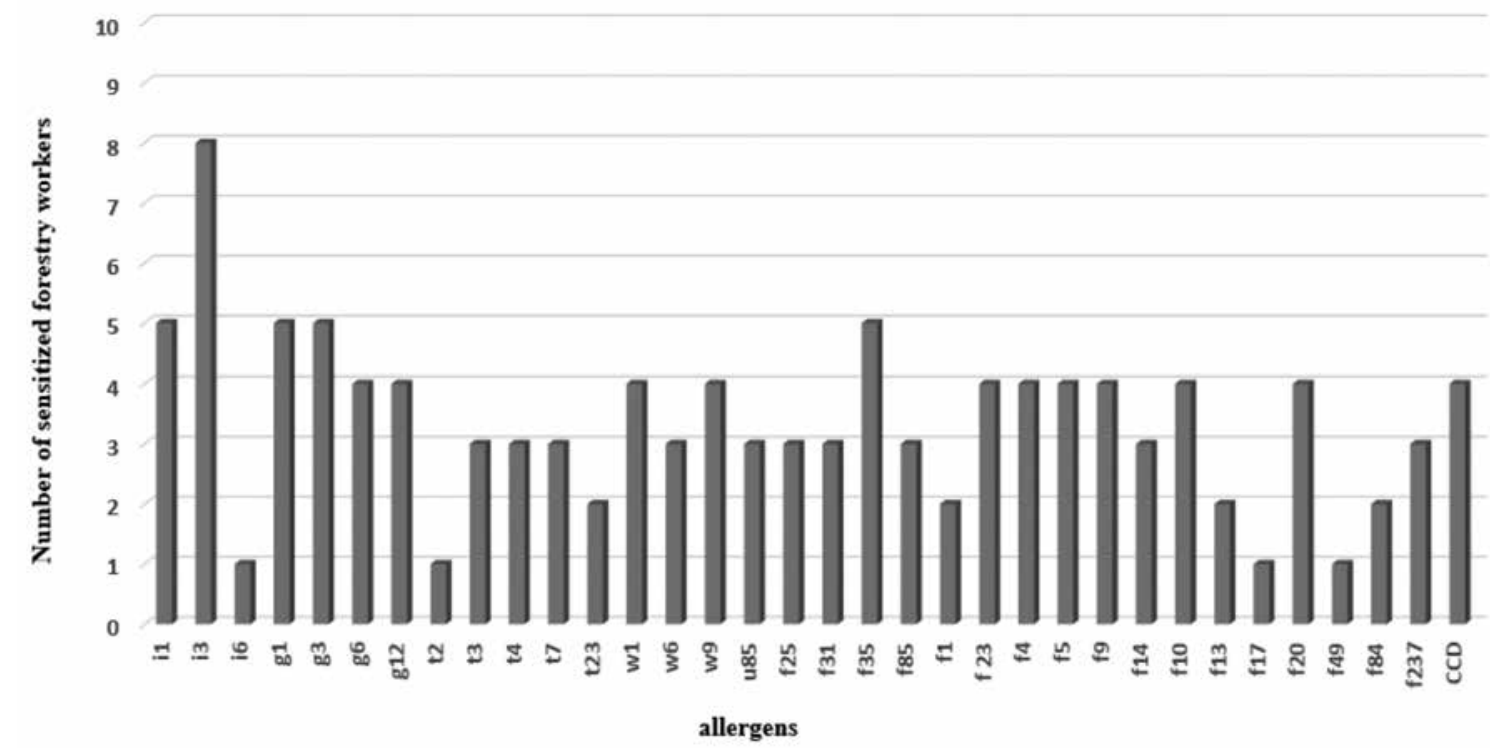

breathing was also observed in $4(28 \%)$ of the participants with allergic symptoms in the present study.

In the literature there are several possible explanations for the pathogenetic mechanism of the inflammatory response developed after contact with the urticogenic hairs of the different Thaumetopoea caterpillars. Several studies have described that hairs contain a specific protein (taumetopoein) that has a direct effect on mast cells and leads to their degranulation and the release of histamine from their granules [9]. In addition to the direct histaminoliberation, the symptoms are also associated with the presence of IgE-mediated hypersensitivity. A contemporary study of a crude allergen extract from a pine processionary demonstrates that it contains a mixture of at least 70 proteins, including 7 allergenic molecules that penetrate the skin and mucous membranes after exposure to caterpillar hairs and are able to sensitize the organism [10].

The data obtained through the skin prick tests with the different Thaumetopoea allergens, developed especially for this study, demonstrate that hypersensitivity to different processionary species was present in $48 \%$ of the studied forestry workers.

These results are in line with data from a European study, which found that around half of the patients with allergic symptoms after contact with Thaumetopoea pityocampa showed a positive allergy reaction after skin testing with the relevant allergen [11].

Summarizing the obtained results, we can state that at least $19 \%$ percent of the studied forestry workers reported for symptoms following the contact with the different Thaumetopoea caterpillars, which have immunological pathogenesis and involve an IgE-mediated mechanism. Therefore, the presence of the IgE-mediated allergy to caterpillar allergens should be assessed as early as possible in order to avoid a progressive increase in sensitization after continuous contact with the Thaumetopoea allergens.

As far not all sensitized individuals develop allergic symptoms after exposure to Thaumetopoea allergens, in a large percentage (56\%) of the study participants we observe asymptomatic sensitization. Moreover, in the sera of 13 (39\%) forestry workers increased levels of total IgE, were found and assessment of the allergen-specific IgE to a set of 34 inhalative, insect and food allergens, demonstrate the high prevalence of insect allergy, mostly to wasps and bee venom.

\section{Conclusion}

This study provided important information on the impact of the different Thaumetopoea species on the health of the people working daily in the forests and having frequent contact with processionary caterpillars. The initial assessment of the sensitization of the forestry workers in Bulgaria also outlined the key role of different environmental allergens in the occupational environment for the development of symptoms of IgE-mediated allergy and the need for more detailed epidemiologic and allergic and large study on the medico-social importance of the sensitization to Thaumetopoea species.

This study is supported by research grant DN01/17/ 22.12.2016, Bulgarian National Science Fund. 


\section{References}

1. Haeberle M. Forestry Workers. In: John S., Johansen J., Rustemeyer T., Elsner P., Maibach H. (eds) Kanerva's Occupational Dermatology. 2018 Springer, Cham.

2. Copertaro A, Pucci S, Bracci M, Barbaresi M. Hymenoptera stings in forestry department agents: evaluation of risk. Med Lav. 2006; 97: 676-681.

3. Giannandrea F, Brandi G, Bemardini P. Hymenoptera sting arthropathy as an occupational injury: a case report. G Ital Med Lav Ergon. $2005 ; 27: 250-252$.

4. Hossler EW. Caterpillars and moths: part I. Dermatologic manifestations of encounters with Lepidoptera. J Am Acad Dermatol. 2010; 62: 1-10.

5. Hossler EW. Caterpillars and moths: part II. Dermatologic manifestations of encounters with Lepidoptera. J Am Acad Dermatol. 2010; 62: 13-28.

6. Vega JM, Moneo I, Armentia A et al. Anaphylaxis to a pine caterpillar. Allergy. 1997; 52 (12): 1244-1245.

7. Fuentes Aparicioa V., de Barrio Fernándezb M., Rubio Sotésb M. et al. Non-occupational allergy caused by the pine processionary caterpillar (Thaumetopoea pityocampa). Allergol et Immunopathol. 2004; 32 (2): 69-75

8. Mirchev, P., Georgiev G., Matova M. Prerequisites for Expansion of Pine Processionary Moth Thaumetopoea pityocampa (Den. \& Schiff.) in Bulgaria. Journal of Balkan Ecology. 2011; 14 (2): 117-130.

9. Vega J, Vega JM, Moneo I. et al. Occupational immunologic contact urticaria from pine processionary caterpillar (Thaumetopoea pityocampa): experience in 30 cases. Contact Dermatitis. 2004; 50:60-64.

10. Bonamonte D, Foti C, Vestita M, Angelini G. Skin reactions to pine processionary caterpillar Thaumetopoea pityocampa Schiff. The Scientific World Journal. 2013; Article ID $867431,1-6$.

11. Vega JM, Moneo I, Ortiz JC. Prevalence of cutaneous reactions to the pine processionary moth (Thaumetopoea pityocampa) in an adult population. Contact Dermatitis. 2011; 64 (4): 220-228.

\section{Об авторах}

- Яна Кандова - лаборатория аллергии Национального центра инфекционных и паразитарных болезней Болгарии. labalerg@ncipd.org. https://orcid.org/0000-0003-2765-7558.

- Грегор Николов - д. м. н., профессор, руководитель лаборатории аллергии Национального центра инфекционных и паразитарных болезней, labalerg@ncipd.org. https://orcid.org/0000-0003-2949-7834.

- Богдан Петрунов - д. м. Н., академик Болгарской академии наук, лаборатория аллергии Национального центр инфекционных и паразитарных болезней, labalerg@ncipd.org. https://orcid.org/0000-0001-8435-6175

Поступила: 09.12.2019. Принята к печати: 05.02.2020.

Контент доступен под лицензией СС ВY 4.0.

\section{About the Authors}

- Yana Kandova - allergy laboratory of the National Center for Infectious and Parasitic Diseases of Bulgaria. labalerg@ncipd.org. https://orcid.org/00000003-2765-7558.

- Gregor Nikolov - Dr. Sci. (Med.), professor, head of the allergy laboratory of the National Center for Infectious and Parasitic Diseases. labalerg@ncipd. org. https://orcid.org/0000-0003-2949-7834.

- Bogdan Petrunov - Dr. Sci. (Med.),, academician of the Bulgarian Academy of Sciences, Allergy Laboratory of the National Center for Infectious and Parasitic Diseases. labalerg@ncipd.org. https://orcid.org/0000-0001-8435-6175

Received: 09.12.2019 Accepted: 05.02.2020.

Creative Commons Attribution CC BY 4.0.

ИНФОРМАЦИЯ ЕРБ ВОЗ

\section{Передовые методы профилактики инфекций и инфекционного контроля с особым}

\section{вниманием к COVID-19: страны делятся опытом}

Неэффективные методы профилактики инфекций и инфекционного контроля (ПИИК), применяемые в процессе ежедневного оказания медицинской помощи, ежегодно наносят вред миллионам пациентов во всем мире. Инфекции, связанные с оказанием медицинской помощи (ИСМП), входят в число наиболее распространенных осложнений после госпитализации; среди них также встречаются инфекции, устойчивые к противомикробным препаратам. Ни одна страна, территория или система здравоохранения не может похвастаться полным отсутствием ИСМП.

25-26 февраля 2020 г. в Копенгагене (Дания) координаторы по ПИИК и эксперты из 15 государств-членов Европейского региона ВОЗ приняли участие во втором двухдневном совещании, посвященном передовым подходам к внедрению основных компонентов программ ПИИК. Второй день мероприятия был посвящен теме ПИИК в контексте вспышки коронавирусной инфекции (COVID-19). Целью совещания было провести очередную оценку нынешнего уровня внедрения восьми основных компонентов ПИИК и представить накопленный странами и субрегионами опыт.

"COVID-19 - это проблема, с которой в настоящее время столкнулись все медицинские специалисты, - сказал Mitchell J Schwaber, директор Национального центра инфекционного контроля при Министерстве здравоохранения Израиля. - Очень важно делиться друг с другом идеями, мнениями, а также имеющимися опасениями и делать выводы из опыта других коллег".

Прибывшие на совещание специалисты приняли участие в семинаре, обсуждениях и имитационных учениях, призванных дать им более четкое представление о сложностях и вызовах, связанных с COVID-19, и локализацией возможных вспышек, а также ознакомить их с имеющимися инструментами и ресурсами.

ЕРБ ВОЗ продолжает оказывать активную поддержку государствам-членам в проведении оценки состояния их программ ПИИК, чтобы определить шаги, которые необходимо предпринять для полномасштабного внедрения основных компонентов ПИИК на уровне стран, территорий и учреждений, оказывающих неотложную медицинскую помощь.
В настоящее время работа над преодолением вызовов в сфере ПИИК (не только в контексте COVID-19, но также в связи с любым инфекционным заболеванием, которое может передаваться от человека человеку) предполагает проведение дополнительной подготовки специалистов с тем, чтобы научить их выявлять лиц, подвергшихся риску инфицирования; повысить их осведомленность о надлежащих мерах, которые необходимо принимать в медицинских учреждениях в случае выявления пациентов, подвергшихся риску инфицирования; обучить их эффективным методам лечения таких пациентов при одновременном обеспечении безопасности окружающих.

"В настоящее время медицинские работники ждут, что специалисты по ПИИК предоставят им ответы на многочисленные злободневные вопросы, - сказал в заключение директор Schwaber. - Данное coвещание дало нам возможность получить ответы на некоторые из этих вопросов, отработать возможные варианты дальнейшего развития событий и получить дополнительную информацию о стоящих перед нами проблемах и имеющихся ресурсах для борьбы с ними, которую мы надеемся использовать, вернувшись в наши страны".

Восемь основных компонентов ПИИК: программы ПИИК; руководства по ПИИК; обучение и подготовка; эпиднадзор; многомодальные стратегии; мониторинг и аудит практических методов ПИИК и обратная связь; рабочая нагрузка; кадровое обеспечение и средняя занятость койко-мест в отделениях неотложной медицинской помощи; рабочая среда, материалы и оборудование для ПИИК на уровне учреждений неотложной медицинской помощи.

Источник: http://www.euro.who.int/en/healthtopics/health-emergencies/coronavirus-covid-19/news/ news/2020/3/best-practices-for-infection-preventionand-control,-with-a-spotlight-on-covid-19-countries-shareexperiences 